\title{
Comparison of enzyme-linked immunosorbent assay (ELISA) and complement fixation test for detection of Mycoplasma pneumoniae antibodies
}

\author{
E DUSSAIX, A SLIM, P TOURNIER
}

From the Laboratoire de Microbiologie, Université Paris XI, Hôpital de Bicêtre 94270, Le Kremlin-Bicêtre, France

SUMMARY An enzyme-linked immunosorbent assay (ELISA) for the detection of IgG and IgM antibodies against Mycoplasma pneumoniae, performed with commercial antigen and reagents, is $\infty^{\infty}$ compared with the complement fixation test (CF) in a serological study of 209 human sera. Concordant results were usually obtained by CF test and by IgG ELISA in sera from patients with $\vec{T}$ recent $M$ pneumoniae infection. In contrast, when used for an immunological survey of a general $\frac{\mathbb{D}}{5}$ population, approximately $27 \%$ of the sera negative in the CF test were positive for IgG by the ELISA, and sera with low CF titres were found to have a broad range of IgG titre by the ELISA. This may be due to the greater sensitivity of the ELISA technique and/or to different types of $\vec{\oplus}$ antibody measured by both tests. IgM was detected by ELISA in sera from all patients with recent $\stackrel{\infty}{\omega}$ $M$ pneumoniae infection diagnosed on the basis of clinical findings and by CF assay. Occasionally false-positive IgM antibodies were due to rheumatoid factor (RF); this potential interference necessitates routine testing of IgM antibody positive sera for RF.

The complement fixation (CF) test is the most commonly used method to detect antibodies against Mycoplasma pneumoniae although other more sensitive techniques, including metabolic inhibition, ${ }^{1}$ indirect immunofluorescence, ${ }^{23}$ mycoplasmacidal $^{4}$ and radioimmunoprecipitation ${ }^{5}$ tests, have been proposed. The latter methods are, however, timeconsuming and/or require specialised equipment. Recently, Busolo et $a l^{b}$ and Räisänen $e t$ al have applied the enzyme-linked immunosorbent assay (ELISA) to the diagnosis of M pneumoniae infection. Busolo et al have used as antigen an $M$ pneumoniae saline suspension. Their results suggest that ELISA is specific and that its sensitivity lies between those of the metabolic inhibition and radioimmunoprecipitation assays. Räisänen et al, using an antigen obtained by Tween-ether-treatment, have found that ELISA, in contrast with CF test, does not show falsepositive reactions in patients with acute pancreatitis.

In this report, we describe a simple and rapid immunoenzymatic assay performed with commercial protein-antigen and reagents and compare the results obtained by this test with those obtained by conven-

Accepted for publication 1 September 1982 tional CF. We also investigate its suitability for the detection of $M$ pneumoniae specific IgM antibody.

\section{Material and methods}

\section{SERUM SPECIMENS}

Two hundred sera obtained from children and adults admitted to Bicêtre Hospital were tested. Among them, 117 (group 1) were collected from patients having no respiratory symptoms nor any clinical indication of $M$ pneumoniae infection; 40 (group 2)은 from patients, with pneumonia, whose paired sera $>$ (acute and convalescent phase) had CF titres to $M$ ‥ pneumoniae of $\leqslant 32$ and no significant rise in CF titres of both samples; 43 (group 3) from patients, with pneumonia, whose sera showed either a fourfold (or $O$ greater) rise in CF titre to $M$ pneumoniae indicating a $\omega$ recent infection, or an unchanged mostly high CF titre $(\geqslant 64)$ in both sera, which suggests a possible recent infection.

In addition we tested nine sera (group 4) from six $\stackrel{\oplus}{+}$ patients with pneumonia (except one, with Reiter's $\frac{0}{T}$ syndrome) who carried $M$ pneumoniae in the throat $\stackrel{+}{\mathbb{\Phi}}$ (except one in the conjunctiva). These sera (kindly $\stackrel{?}{\stackrel{P}{ }}$ supplied by Dr Bonissol, Hospital Necker-Enfants $\stackrel{\mathbb{\Omega}}{\circ}$ Malades, Paris) had negative or low CF titres to $M$ 
pneumoniae except for two. Acute and convalescent phase sera were obtained for only three patients and, in these paired sera, antibody titres by CF were stationary.

All sera were inactivated at $56^{\circ} \mathrm{C}$ for $30 \mathrm{~min}$ and stored at $-20^{\circ} \mathrm{C}$ until use.

\section{COMPLEMENT FIXATION TEST}

The tests were carried out by Microtitre method using two units of complement, two units of $M$ pneumoniae antigen (purchased from Behring Institut, Behringwerke AG, Marburg) and overnight fixation at $4^{\circ} \mathrm{C}$. Sera which gave a reciprocal titre of $\geqslant 8$ were recorded as positive.

\section{ELISA PROCEDURE}

The tests were performed essentially as described by Voller and Bidwell, ${ }^{8}$ using a unit volume of $100 \mu \mathrm{l} . M$ pneumoniae antigen ( $M$ pneumoniae protein antigen for enzyme immunoassay), purchased from Orion Diagnostica, was obtained after Tween-ether treatment of the aqueous phase from chloroformmethanol treated $M$ pneumoniae saline suspension. It contains $140 \mu \mathrm{g}$ of protein in stock preparation. Goat antihuman IgG $(\mathrm{H}+\mathrm{L}$ chain specific) and

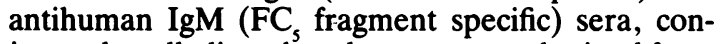
jugated to alkaline phosphatase, were obtained from Dynatech Laboratories.

Optimal dilutions of reagents were previously determined by chessboard titrations. Antigen, diluted at $1 / 48$ in coating buffer, was incubated overnight at room temperature in each well of microtitre plates M 129B (Dynatech Laboratories). Phosphate-buffered saline, containing $0.05 \%$ of Tween 20 and $0.1 \%$ of bovine serum albumin (PBST-BSA), was used for serum and conjugate dilutions. All serum samples were tested at $1 / 20$ and distributed in duplicate in the wells. Anti-IgG and anti-IgM conjugates were used at $1 / 500$ and $1 / 400$ respectively. Sera and conjugates were each incubated for $90 \mathrm{~min}$ at $37^{\circ} \mathrm{C}$. The following controls were included in each plate: a known negative serum, a positive reference serum with a CF titre to M pneumoniae of 512 and an $M$ pneumoniae-specific IgM CF titre of 64 after serum fractionation by sucrose density gradient. ${ }^{9}$ In each plate, the positive reference serum was diluted from $1 / 20$ to $1 / 10240$. A control containing PBS-TBSA instead of human serum was also included.

Optical density at $405 \mathrm{~nm}(\AA 405)$ was determined in a Titertek Multiskan ELISA reader (Flow Laboratories). Sera that gave a photometer reading for IgG, as well as for IgM, of 0.3 (twice the background level) or greater were regarded as positive. Their antibody titres were calculated in conjunction with the standard curve obtained from serial twofold dilutions of positive reference serum whose titrations in 10 separate trials gave results for IgG and IgM which did not vary more than twofold.

Specificity of the conjugates was checked by testing each fraction of eight fractionated sera for $M$ pneumoniae IgG and IgM by ELISA. No detectable crossreaction between the anti-IgG and anti-IgM conjugates was found.

\section{RHEUMATOID FACTOR ASSAY}

In order to exclude the false-positive IgM antibody results due to rheumatoid factor (RF), all sera found positive by ELISA for IgM were absorbed with a suspension of latex particles coated with aggregated human IgG (latex-RF-reagent, Behringwerke, AG) and retested by ELISA for $M$ pneumoniae IgM antibodies. The absorption was performed as described $^{10}$ by mixing $100 \mu \mathrm{l}$ of test serum and $200 \mu \mathrm{l}$ of washed latex suspension diluted at $1 / 10$ and $1 / 2$ respectively in PBS-BSA.

\section{Results}

COMPARISON OF ELISA AND CF TEST FOR

THE DETECTION OF M PNEUMONIAE

ANTIBODIES

Figure 1 shows the antibody titres against $M$ pneumoniae of 117 sera obtained from group 1 patients and determined by the $\mathrm{CF}$ test and by ELISA using anti-IgG conjugate. Among the sera, $85(72.6 \%)$ gave concordant results with $33(28 \cdot 2 \%)$ negative and $52(44.4 \%)$ positive by both methods. However, the positive sera had ELISA titres which were usually higher than those by CF. The geometric mean titre was 95.7 by ELISA and 14.3 by CF. No serum was positive by $\mathrm{CF}$ and negative by ELISA. In contrast, 32 sera $(27.4 \%)$ were found to be negative

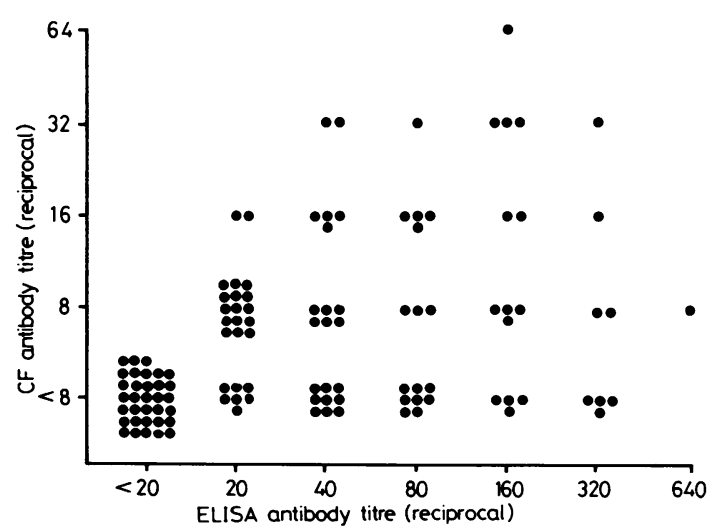

Fig. 1 Relation between $M$ pneumoniae antibody CF titres and $M$ pneumoniae IgG antibody ELISA titres of 117 human sera (group 1 patients) 
by $\mathrm{CF}$ and positive by ELISA. Among the latter, 24 came from adults older than $35 \mathrm{yr}$, four from oneyear-old children, and four from newborns.

All sera were negative for $M$ pneumoniae specific IgM antibody by ELISA except for four which became negative after latex IgG absorption.

Paired sera from 20 patients of group 2, with $\mathrm{CF}$ titres to $M$ pneumoniae $\leqslant 32$ and without a rise in CF titre between both samples, were also tested by ELISA. In all cases, no change in the titre of the sera was detected. As shown in Table 1, in eight paired sera, no antibody was demonstrated by either test. On the other hand, a significant rise in CF titre to one of the following agents: respiratory syncytial virus (RS), rotavirus, Chlamydia psittaci and parainfluenza virus (type 3), was seen in four of these paired sera. In five patients, the sera which showed low antibody titres by $C F$ were also low by ELISA. In seven cases, the paired samples which were negative by $\mathrm{CF}$, were positive by ELISA (these sera were obtained from adults older than 45 except for two obtained from newborns). None of these 40 sera had detectable $M$ pneumoniae-specific antibody.

Table 1 Comparison of ELISA and CF tests for detection of $M$ pneumoniae antibodies in sera from patients with pneumonia and with stationary low CF titres to M pneumoniae (group 2)

\begin{tabular}{llr}
\hline No of paired sera & $* C F$ & $+E L I S A$ \\
\hline 8 & $<8 /<8$ & $<20 /<20$ \\
3 & $<8 /<8$ & $40 / 40$ \\
2 & $<8 /<8$ & $80 / 80$ \\
2 & $<8 /<8$ & $160 / 160$ \\
1 & $8 / 8$ & $20 / 20$ \\
2 & $16 / 16$ & $80 / 80$ \\
2 & $32 / 32$ & $80 / 80$ \\
\hline
\end{tabular}

- CF titres of acute and convalescent phase sera.

† ELISA IgG antibody titres of acute and convalescent sera.
PATIENTS WITH RECENT M PNEUMONIAE INFECTION

Acute and convalescent phase sera from 20 patients with $M$ pneumoniae infection (group 3) were examined. The results are presented in Fig. 2. Among nine patients with a significant increase in the CF titre, all also showed a fourfold or greater rise in IgG titre. Diagnosis of $M$ pneumoniae infection could be based on a fourfold increase in titre determined by conventional methods or by ELISA. The paired sera of remaining patients had stationary antibody titres by both CF test and by IgG ELISA. The IgG ELISA titres were usually higher in patients over $20 \mathrm{yr}$ old.

IgM antibody to $M$ pneumoniae was found by ELISA in one or both serum specimens from all patients. All sera were negative for RF and IgM 405 nm ( $\AA$ 405) values remained unchanged after the latex absorption procedure. In two of seven patients under $20 \mathrm{yr}$ the IgM antibody ELISA titre was found to be significantly greater than the IgG. In 13 patients older than $20 \mathrm{yr}$, no similar observation could be made. In contrast, a predominance of IgG to IgM antibody was observed in 11 of these patients as against only one under $20 \mathrm{yr}$. In the last serum of one patient collected almost two months after the onset of the disease, IgM was still detectable (data not shown).

Table 2 shows the ELISA results of six patients who were $M$ pneumoniae culture-positive (group 4). IgG antibody to $M$ pneumoniae was found by ELISA in all sera except in one (No 5) which was also negative by CF test and for IgM ELISA. It should be mentioned that this serum was obtained the day of the onset of illness. The IgG ELISA antibody titres were in all other cases higher than those of CF.

IgM antibody to $M$ pneumoniae was demonstrated by ELISA in four of six cases. Patient No 3 who had very low IgM and relatively low IgG by ELISA was under immunosuppressive therapy.

Table 2 ELISA antibody titres in sera from six patients (group 4) who were culture-positive but had negative or low CF antibody titre except for one

\begin{tabular}{|c|c|c|c|c|c|c|c|}
\hline \multirow[b]{3}{*}{ No } & \multirow[b]{3}{*}{ Age (yr) } & \multirow[b]{3}{*}{ Diagnosis } & \multirow{3}{*}{$\begin{array}{l}\text { Days after } \\
\text { onset of } \\
\text { illness }\end{array}$} & \multicolumn{3}{|c|}{ M pneumoniae antibody } & \multirow{3}{*}{$\begin{array}{l}\text { M pneumoniae } \\
\text { isolation }\end{array}$} \\
\hline & & & & \multirow[t]{2}{*}{ CF titre } & \multicolumn{2}{|c|}{ ELISA titre } & \\
\hline & & & & & $\operatorname{Ig} G$ & $\operatorname{IgM}$ & \\
\hline 1 & 4 & pneumonia & $\begin{array}{l}15 \\
25\end{array}$ & $\begin{array}{l}64 \\
32\end{array}$ & $\begin{array}{l}80 \\
80\end{array}$ & $\begin{array}{l}160 \\
160\end{array}$ & $\stackrel{+}{\text { ND }}$ \\
\hline 2 & 3 & pneumonia & 22 & $\begin{array}{l}16 \\
16\end{array}$ & 80 & $\leqslant 20$ & $\stackrel{+}{\text { ND }}$ \\
\hline 3 & 50 & pneumonia & 7 & $<8$ & 80 & 20 & + \\
\hline $\begin{array}{l}4 \\
5 \\
6\end{array}$ & $\begin{array}{l}5 \\
2 \text { months } \\
39\end{array}$ & $\begin{array}{l}\text { Reiter's syndrome } \\
\text { pneumonia } \\
\text { pneumonia }\end{array}$ & $\begin{array}{r}30 \\
1 \\
7\end{array}$ & $\begin{array}{c}< \\
<8 \\
8\end{array}$ & $\begin{array}{r}80 \\
<20 \\
80\end{array}$ & $\begin{array}{r}80 \\
<20 \\
<20\end{array}$ & $\begin{array}{l}+ \\
+ \\
+\end{array}$ \\
\hline
\end{tabular}




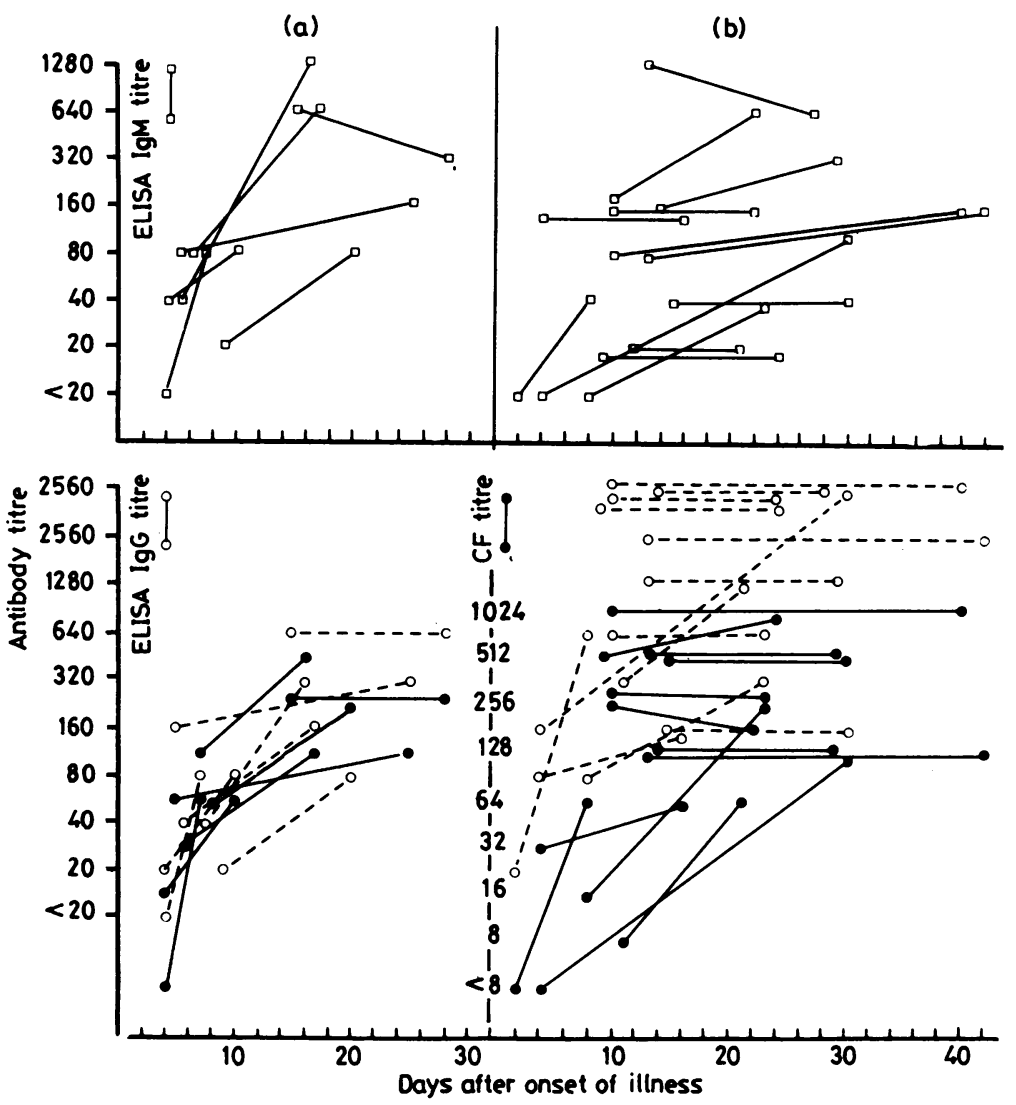

Fig. 2 CF and ELISA antibody titres in sera from (a) seven patients younger than $20 \mathrm{yr}$ and (b) 13 patients older than $20 \mathrm{yr}$ with recent $M$ pneumoniae infection (group 3)

\section{Discussion}

We describe here an ELISA for the detection of $M$ pneumoniae antibodies using commercial proteinantigen and reagents. Our results suggest that it is specific for the serological diagnosis of $M$ pneumoniae infection, firstly by the absence of ELISA titres in sera which have a significant increase in CF titre to other respiratory organisms (C psittaci, parainfluenza and RS viruses) and, secondly by the concordant results obtained with ELISA and CF tests in paired sera from group 2 and 3 patients. However, for the determination of immune status (group 1 patients), there is a poor correlation between the results of the two tests. The sera with low CF titres show a wide range of IgG ELISA titres and, in contrast, a high proportion of sera which are found negative by the CF test (27\%) are positive by ELISA. The lack of correlation between the antibody levels determined by the two methods can be due to the greater sensitivity of the ELISA technique. This is also indicated by the ability to demonstrate relatively high ELISA absorbance values in sera from group 4 patients which have only low CF antibody levels. But it can be due also to the different types of antibody detected by the two tests. Indeed, the CF test measures only antibody against the glycolipids of $M$ pneumoniae whereas ELISA measures especially antibody against the protein components of this micro-organism. For the determination of immunity, the discordance between the results is usually observed for sera obtained from elderly adults and from newborns (whose antibodies can be considered as passively acquired from the mother). It is possible that the antibodies detected with Tween-ether antigen persist for a longer period after an $M$ pneumoniae infection than the CF antibodies.

On the other hand, ELISA appears to be an efficient method for demonstrating $M$ pneumoniae specific IgM antibody even though RF can give false- 
positive results in a few instances $(2 \%)$. However, the ELISA seems to be the most suitable for routine measurement of IgM antibody over other techniques, such as indirect immunofluorescence or radioimmunoassay. Indeed, the estimation of antibody by indirect immunofluorescence is often subjective and radioimmunoassay requires equipment unavailable in many diagnostic laboratories. Furthermore, RF can also interfere with the detection of IgM antibody particularly in indirect immunofluorescence test. ${ }^{11}$

In our study, sera from all patients with recent $M$ pneumoniae infection diagnosed on clinical findings and by CF test (group 3 patients) have specific IgM antibody (titre $\geqslant 20$ ). Our results concerning the IgM:IgG ratio in these patients are in agreement with those previously reported ${ }^{2} 3512$ and confirm the predominance of IgG over IgM in patients over $20 \mathrm{yr}$.

Two of five patients (group 4) in whom $M$ pneumoniae was detected had no specific IgM antibody by ELISA. In one case, the serum was received the day of the onset of illness and in the other, seven days after. Unfortunately, no convalescent phase sera were obtained from these patients.

The present study in agreement with previous reports $^{36}$ shows that $M$ pneumoniae specific IgM antibody may persist in the patient for up to two months (to 1 year) after infection. Thus the detection of IgM ( titre $\geqslant 20$ ), in a single serum does not indicate accurately the time of onset of the illness. In contrast, the absence of $M$ pneumoniae IgM antibody in a serum collected 10-20 days after the onset of pneumonia can exclude a current $M$ pneumoniae infection, especially among children.

\section{References}

${ }^{1}$ Taylor-Robinson D, Purcell RH, Wong DC, Chanock RM. A colour test for measurement of antibody to certain Mycoplasma species based upon the inhibition of acid production. $J$ Hyg 1966;64:91-104.

${ }^{2}$ Biberfeld G. Antibody responses in Mycoplasma pneumoniae infection in relation to serum immunoglobulins, especially IgM. Acta Pathol Microbiol Scand 1971;79:620-34.

${ }^{3}$ Skaug K, Eng J, Orstavik I, Haug KW. The diagnostic value of determination of IgM antibodies against Mycoplasma pneumoniae by the indirect immunofluorescent test. Acta Pathol Microbiol Scand 1976;84:170-6.

${ }^{4}$ Brunner H, James WD, Horswood RL, Chanock RM. Measurement of Mycoplasma pneumoniae mycoplasmacidal antibody in human serum. J Immunol 1972;108:1491-8.

${ }^{5}$ Brunner H, Chanock RM. A radioimmunoprecipitation test for detection of Mycoplasma pneumoniae antibody. Proc Soc Exp Biol Med 1973;143:95-105.

${ }^{6}$ Busolo F, Tonin E, Conventi L. Enzyme-linked immunosorbent assay for detection of Mycoplasma pneumoniae antibodies. $J$ Clin Microbiol 1980;12:69-73.

${ }^{7}$ Räisänen S, Suni JI, Leinikki P. Serological diagnosis of Mycoplasma pneumoniae infection by enzyme immunoassay. $J$ Clin Pathol 1980;33:836-40.

${ }^{8}$ Voller A, Bidwell DE. A simple method for detecting antibodies to rubella. J Exp Pathol 1975;56:338-9.

${ }^{9}$ Vesikari T, Vaheri A. Rubella: a method for rapid diagnosis of a recent infection by demonstration of the IgM antibodies. $\mathrm{Br}$ Med J 1968;i:221-3.

${ }^{10}$ Kryger P, Mathiesen LR, Møller AM, Aldershvile J, Hansson BG, Nielsen JO. Enzyme-linked immunosorbent assay for detection of immunoglobulin $\mathbf{M}$ antibody to hepatitis B core antigen. J Clin Microbiol 1981;13:405-9.

${ }^{11}$ Shirodaria PV, Fraser KB, Standford F. Secondary fluorescent staining of virus antigen by rheumatoid factor and fluorescein conjugated anti-IgM. Ann Rheum Dis 1973;32:53-7.

${ }^{12}$ Colimon R, Ferchal F, Bertrand C, Perol Y. Recherche des anticorps de type IgM après fractionnment des sérums sur gradients de saccharose chez l'enfants et chez l'adults suspects d'infection à Mycoplasma pneumoniae. Pathol Biol 1980;28:567-74.

Requests for reprints to: Dr Elizabeth Dussaix, Laboratoire de Microbiologie, Université Paris XI, Hôpital de Bicêtre, 94270, Le Kremlin-Bicêtre, France. 